\title{
EFFECT OF MANAGEMENT COMMITMENT TO INTERNAL MARKETING ON EMPLOYEES' SATISFACTION. A CASE STUDY: IMAM JAFAR SADEGH HOSPITAL NURSES
}

\author{
Ali Morovati Sharifabadi ${ }^{*}$ and Shima Shahhosseini Bideh ${ }^{2}$

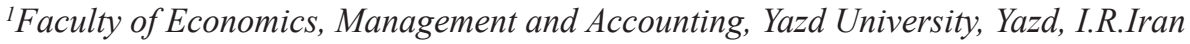 \\ ${ }^{2}$ Islamic Azad University, Yazd Branch, Yazd, I.R.Iran \\ *Corresponding author: alimorovati@yazd.ac.ir
}

Published online: 30 December 2016

To cite this article: Ali Morovati, S., and Shima Shahhosseini, B. (2016). Effect of management commitment to internal marketing on employees' satisfaction. A case study: Imam Jafar Sadegh hospital nurses. Asian Academy of Management Journal, 21(2), 135-152. http://dx.doi.org/10.21315/aamj2016.21.2.6

To link to this article: $\mathrm{http}: / / \mathrm{dx}$.doi.org/10.21315/aamj2016.21.2.6

\begin{abstract}
Nowadays, healthcare is an extraordinarily people-centric industry and employees play important roles in the product/service exchange. Internal marketing (IM) forces the employee to treat more hospitably facing customers. The present study examines the effect of management commitment to internal marketing (MCIM) on employees' satisfaction through IM practices. Data were collected from 110 nurses of Imam Jafar Sadegh hospital. The results of structural equation modeling showed the significant effect of MCIM on IM practices (formal internal marketing, informal internal marketing and responsiveness). But verse to what was assumed, there was no significant relation between IM and employees' satisfaction.
\end{abstract}

Keywords: management commitment to internal marketing (MCIM), formal internal marketing, informal internal marketing, responsiveness, employees' satisfaction.

\section{INTRODUCTION}

The first usage of the term internal marketing (IM) concept appeared with Berry, Hensel \& Burk (1976) Berry et al. (1976), followed by George (1977) and Murray (1979). Later, Berry (1981) defined IM as "viewing employees as 
internal customers, viewing jobs as internal products." (Martin \& To, 2013). This view implies that for having satisfied customers, the firm must also have satisfied employees. They should be viewed as internal customers. (Rafiq \& Ahmad, 1993). As it was argued by Arnett, Laverie \& Mclane (2002)Arnett et al. (2002) IM must precede external marketing because it makes no sense to promote excellent service before employees are motivated to provide it (To, Martin \& Yu, 2015). Berry and Parasuraman (1991) also stated that "internal marketing is attracting, developing, motivating and retaining qualified employees through job-products that satisfy their needs."(Rafiq \& Ahmad, 1993). According to the proposed definitions, the concept of IM in the health care sector suggests that the best way to satisfy patients is by viewing employees as internal customers and understanding and meeting employees' needs, wants, and expectations. Health care is an extraordinarily public oriented industry, in which employees play an important role in the product/service exchange (Peltier \& Scovotti, 2004). Unfortunately, many health care institutions lack the strategic insight for designing and implementing research programs to address the role of nurses in the care-giving process, and how their satisfaction and loyalty impact patients' care, satisfaction, and profitability (Cooper \& Cronin 2000; Peltier, Nill \& Schibrowsky, 2003; Woods \& Cardin 2002). Employees' satisfaction and retention are critical issues that influence the success of the organization (Peltier, Pointer \& Schibrowsky, 2006). Only recently have health care researchers begun to direct attention to the use of relationship marketing, IM and related business oriented concepts to explore ways to improve job satisfaction and nurses' loyalty (Melten, Eveleth \& Bailey, 2005; Peltier \& Scovotti, 2004; Peltier et al., 2006).

Past research has investigated the effect of management commitment to different aspects such as quality management (Ahire \& O'Shaughnessy, 1998), technological adoption (Cascio, Mariadoss \& Mouri, 2010), and service quality (Cheung \& To, 2010; Kim, Tavitiyaman \& Kim, 2009), on employees' attitudes ,satisfaction and organizational performance. Moorman, Zaltman \& Dehpande (1992) Moorman et al. (1992) defined commitment as constant willingness to keep long term and valuable relations for ever. A key outcome of successful IM is the creation of valuable relations for conveying sense of commitment to service providers (Hogg, Carter, \& Dunn, 1998). According to IM, the organizations can create value for the employees through effective management of relationship among employees, supervisors and managers. Employees experiencing a sense of being appreciated, make a commitment beyond question (Gounaris, 2006).

Given to the importance of nurses' satisfaction in the hospital and the conducted researches into internal marketing, our analysis brings into focus the relationship between MCIM and the satisfaction of the studied nurses. 
In the previous researches on IM and employees' satisfaction, the impact of MCIM is not studied. However, we address salient implications and guidelines on improving employees' satisfaction that follow from our analysis.

By referring to the previous studies related to IM, this study explored MCIM from the employee's perspective. At first the literature review related to IM was collected and hypothesis of the research were constructed. Then approving factors and the modeling technique of constructive equitation applying LISREL software were used to approve the relation between variables and factors which is discussed in the following sections.

\section{LITERATURE REVIEW}

Nowadays IM has been recognized as a strategy for market orientation. The related studies over this ground reveal that IM activities improve organization's competitiveness through influencing and creating of motivation in employees and enhancing competences (Abzari, Ghorbani \& Madani, 2011). IM is not only about creating some meaningless public relations slogans that might perceptually differentiate one organization from another, but also creating a suitable relationship with employees as customers (Stachowski, 2008).

Bansal, Mendelson \& Sharma, (2001) proposed a model that relates six key IM practices to external customer satisfaction and loyalty, mediated by internal customer attitudes (i.e., loyalty to the firm, job satisfaction, trust in management) leading to extra role behaviors directed at external customers and argued that a direct relationship should exist between the commitment of a firm to IM and the financial success of the firm (Bansal et al., 2001). Lings and Greenley (2005) proposed and identified five distinct dimensions of IM, (formal face-toface information generation, formal written information generation, informal information generation, information dissemination, and responsiveness) and from the point of view of employees argued that it has positive impacts on the attitudes and behavior of employees, customers' satisfaction and relative competitive positions (Lings \& Greenley, 2005). Gounaris (2006) followed Lings and Greenley (2005) but reconceptualzed IM to be a three-dimensional construct consisting of internal market intelligence, internal intelligence dissemination and response to intelligence. Dabholkar and Abston (2008), by considering employees as external customers, proposed a conceptual model of the interaction between Firm' controlled aspects (organizational factors, financial internal marketing, and nonfinancial internal marketing), Employees' aspects (job satisfaction, employee patronage, and job performance), Customers' outcomes (perceived service quality and customer 
satisfaction, both by final customers of the organization), Organizational outcomes (long-term relationships with customers, long-term relationships with employees, and profits) and argued that the use of IM practices more satisfied employees and customers as a result of more satisfied and more loyal (Dabholkar \& Abston, 2008). Cascio et al. (2010) found that top management commitment perceived by frontline employees has a strong and significant effect on employees' work behaviors. They further argued that organizations should engage the workforce using IM i.e., through effective communications between managers and employees (Cascio et al., 2010). Martin and To (2013), examined the effect of internal market on organizational performance, including employees' job satisfaction, perceived customers' satisfaction, and relative competitive positions. Moreover, external measures, such as positive reports of corporate reputation in the mass media and positive changes in the market share, were found to be positively associated with perceived customers' satisfaction (Martin \& To, 2013). To et al., (2015), examines the effect of MCIM on employees' work attitudes through IM practices including formal and informal internal communications. Bidirectional formal and informal communications between managers and employees have positive outcomes for employees' work attitudes (To et al., 2015).

\section{Management Commitment to Internal Marketing and Internal Marketing Practices}

Management commitment is the first requirement of implementing IM. Luo, Wieseke, \& Homburg (2012) argued that top management commitment affects the generation, dissemination, and use of internal market and customers' intelligence, i.e., the deployment of IM practices (To et al., 2015). Many authors reviewed IM concepts, activities, processes, and practices. Rafiq and Ahmed (2000) and Lings and Greenley (2005) identified formal internal communication (FIC) and informal internal communication (IIC) as the core elements in IM. They suggested that internal market orientation (IMO) like the generation and dissemination of intelligence pertaining to the wants and needs of employees, and the design and implementation of appropriate responses to meet these wants and needs, may reflect how much managerial commitment to IM exists (Rafiq \& Ahmed, 2000; Lings \& Greenley, 2005). As Stauss and Schulze (1990) recognized, generating and understanding information about the internal exchange will allow employers to formulate appropriate responses to the internal market and to make the internal product (job) more attractive to potential and existing employees than that of competitors' (lings, 2004). Martin and To (2013) confirmed formal internal marketing and informal internal marketing as the key IM practices which are strongly and significantly related to employees' job satisfaction and customers' satisfaction in the gaming industry (Martin \& To, 2013). Sulaiman, Othman, 
Perumal \& Hashim (2013),showed that IM contains the internal generation of intelligence, the dissemination of intelligence and the completion of correct reactions to encounter the requirements of employees (Sulaiman et al., 2013). To et al., (2015) argued that formal internal marketing and informal internal marketing has positive related on employees' satisfaction and attitudes (To et al., 2015). Hence, MCIM should lead to the effectiveness of internal marketing in gathering and disseminating information to all employees via internal communications. Therefore, the following hypotheses are proposed:

H1: management commitment to the internal marketing has a positive effect on the formal internal marketing.

$\mathrm{H} 2$ : management commitment to the internal marketing has a positive effect on the informal internal marketing.

H3: management commitment to the internal marketing has a positive effect on the responsiveness.

\section{Management Commitment to Internal Marketing and Employees' Satisfaction}

Successful management programs require commitment from the top management and employees and IM is no exception. Kilburn (2009) argued that top management commitment is the most important factor that affects the effectiveness of IM in the manufacturing environment (To et al., 2015). Supervisors due to their abutment to the employees can influence Employees' perception and performance (Lings \& Greenley, 2005; to et al., 2015). Employees who recognize top management commitment to employees' needs may reciprocate better work attitudes as expected by top management (Paille \& Boiral, 2013). Cascio et al. (2010), reported that organizations should employ IM to convince employees that top management is committed to enhancing employees' satisfaction, empowerment, and service quality (Cascio et al., 2010). Newman (2001) has highlighted the close links among top management commitment, job satisfaction, and service quality from the perspective of employees. Also, Lings (2004) suggested that MCIM affects internal and external aspects of organizational performance. Internal aspects are employees' retention, motivation, morale, satisfaction and organizational commitment. External aspects of performance are service quality, customers' satisfaction and, ultimately, financial performance (Lings, 2004). Hence, the following hypothesis is proposed:

H4: management commitment to the internal marketing has a positive effect on employees' satisfaction. 


\section{Internal marketing practices and employees' satisfaction}

Job satisfaction is a widely studied concept in many different occupational areas including the health care industry (Peltier et al., 2006); it is also defined as "an employees' overall affective evaluation of the job situation"(Dabholkar \& Abston, 2008). According to studies, manager's IM behaviors lead to higher levels of employees' satisfaction and motivation (Martin \& To, 2013). In this study the effect of MCIM on employees' satisfaction through financial,social and structural bonds has been investigated.

Financial incentives are simple ways to build a relationship bond with employees. Financial incentives typically include salary, fringe benefits in the form of health insurance and retirement benefits. These incentives are generally designed to provide the right monetary incentives to gain employees' satisfaction and loyalty (Peltier et al., 2006). Acker (2004) found that satisfaction with salary positively correlated with job satisfaction of mental health social workers. Peltier, Boyt \& Westfall (1997) suggested that loyalty built solely on financial incentives does not provide a sustainable competitive advantage. Although financial compensation is a necessary component of a nurse's job environment, it is by no means a sufficient antecedent to satisfaction and loyalty (Peltier et al. 2003, 2004). Knowledge generation is one of the critical components of achieving a sustainable competitive advantage. Almost all descriptions of IM practices emphasize the importance of training. The success or failure of organizations is partly contingent on employees' ability to resolve problems, make necessary changes to work procedures, and to guarantee the quality of products and services. Thus, investing in training does have intangible benefits such as improved attitudes and increased skills that may presage higher levels of service quality, customers' satisfaction and loyalty. Training also provides organizational members with the value and culture cherished by the organization and communicates the organization's commitment to their internal customers' career development (Bansal et al., 2001). As Spence Laschinger, Finegan, Shamian \& Wilk (2004) discussed, workplace environments provide nurses with greater access to information, support, and opportunities to learn and grow over time and the experience of higher levels of job satisfaction (Spence Laschinger et al., 2004). Education and training promote feelings of self-worth and professional growth, two key elements for enhancement in the nursing profession (Peltier et al., 2006). Effective involvement means giving employees a certain amount of job autonomy. One of the predictors of better service performance is employees' involvement. Employee's involvement provides opportunities for employees to enhance their skills and discretion in the job and to enjoy their work (Cheung \& To, 2010). Christen, Iyer \& Soberman (2006) found that job autonomy positively influences job satisfaction of grocery store managers. Similarly, in a 
study of hospital employees, Paulin Ferguson \& Bergeron (2006) found that job autonomy had a significant, positive effect on overall job satisfaction; And on examining motivational practices for mid-level health care managers, Timmreck (2006) found a positive influence of motivation on job satisfaction (Dabholkar \& Abston, 2008).

Social bonds cover a much wider array of activities than financial bonds and could include all interpersonal interactions that exist within an organization. Teamwork, cohesion, cooperation, friendliness, shared values, and a supportive work environment have all been found to be important antecedents of nurses' satisfaction and retention. Social exchange theory which refers to how well two parties interact and form dependent relationships. Parties develop emotional bonds over time through the communication process. These ties are critical to maintaining the relationship. Communication is a facilitating dimension between the members of an organization. Positive communication in the forms of empathy, reflective listening, and supportive comments can enable organization members to share their needs (Peltier et al, 2006). Melten et al. (2005) emphasized the need for managers to communicate with contact workers as a way to facilitate better consumer satisfaction (Melten et al., 2005). Within a health care organization, social bonding can take many forms, including social support, connectedness to other staff, caring, empathy, information support, assistance, affirmation, and a host of other relationship-based communications and interactions among nurses and other health care professionals. Adequate communications among these workers are necessary. When good communications exist among nurses and other members in the health care team, the likely result is the higher job performance, increased job satisfaction, and improved quality of care (Peltier et al., 2003). With regard to the provision of appropriate health care for patients in need, structural bonding is in parts a form of collaboration among members in a network in which various stakeholder are grouped (Peltier et al, 2006).

Although structural bonding can take multiple forms, the ones that have received recent attention in health care settings are perceptions of control over care and job flexibility. As such, an essential element for enhancing nurse satisfaction and loyalty is having an internal culture that values the knowledge, experience and perspective that nurses offer to the organization. Nurses' perception of the amount of control they have over the care received by patients, represents feelings of empowerment, which in turn has been found to enhance respect, and organizational trust. Empowerment is an organizational cultural that decentralizes power by involving employees in different levels of collaborating in the decision making process (Peltier et al, 2006). Aiken, Clarke, Sloane, Sochalski \& Silber (2002) showed that nurses working in environments that promote autonomy and control 
over hospital practices were generally more satisfied with their jobs and experienced less burnout. Flexibility improves workers' efficiency and productivity (Kelliher \& Riley, 2003).Increased flexibility in work hours enables nurses to balance their work and family commitments more evenly. It also gives them some autonomy to determine how they will accommodate to their lifestyle with the emotional and physical demands of the job, and to enhance job satisfaction (Peltier et al, 2006). The following hypothesis are proposed:

H5: the formal internal marketing has a positive effect on employees' satisfaction.

H6: the informal internal marketing has a positive effect on employees' satisfaction

H7: the responsiveness has a positive effect on employees' satisfaction.

Also the mediating role of the variables was investigated. Thus, hypotheses are proposed:

H8: management commitment to the internal marketing positively affects employees' satisfaction through the formal internal marketing.

H9: management commitment to the internal marketing positively affects employees' satisfaction through the formal internal marketing.

H10:management commitment to the internal marketing positively affects employees' satisfaction through the responsiveness.

With regard to the hypothesis, figure1 shows the research model of this study, in which MCIM affects Employees' satisfaction via three core IM practices, formal internal marketing, informal internal marketing and responsiveness. The figure illustrates how MCIM can have an impact on Employees' satisfaction.

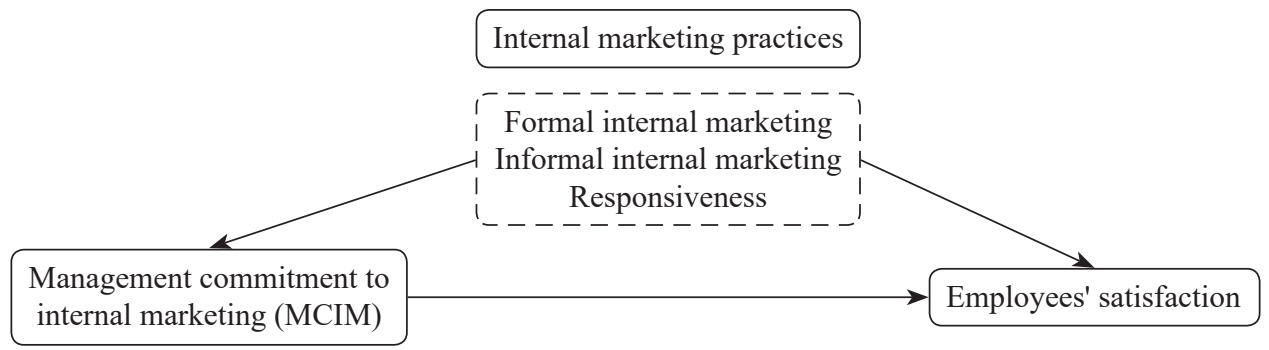

Figure 1. The research model 


\section{METHOLOGY}

The present study used descriptive analysis and is a kind of correlational study. Five variables are used to test the hypothesis. The questionnaires of To et al., (2015) and Lings and Greenly (2005) were used to test the hypothesis and measure MCIM, formal internal marketing, informal internal marketing and responsiveness. To measure employee's satisfaction the questionnaire of Pelletier, Kabush, Vallerand \& Sharp (2007) was used. To verify the relationships between variables and factors, confirmatory factor analysis and structural equation modeling using LISREL software technique was used. Cronbach's alpha coefficient which is used to test the reliability of the designed questions to asses each variable is presented in Table (1).

Table 1

The reliability test using Cronbach's alpha

\begin{tabular}{lcc}
\hline Research variables & $\begin{array}{c}\text { Number of } \\
\text { questions }\end{array}$ & $\begin{array}{c}\text { Cronbach's } \\
\text { Alpha }\end{array}$ \\
\hline Management commitment to internal marketing (MCIM) & 3 & 0.844 \\
Formal internal marketing & 4 & 0.840 \\
Informal internal marketing & 5 & 0.831 \\
Responsiveness & 2 & 0.877 \\
Employees' satisfaction & 28 & 0.921 \\
Total questionnaire & 42 & 0.951 \\
\hline
\end{tabular}

The study consisted of 150 nurses of Imam Jafar Sadiq in Maybod district. Ratio scale and random sampling were used. Number of samples was determined by using the formula for the limited sample size of 110. Demographic characteristics of the samples are presented in Table 2 . As it is visible $72.7 \%$ of respondents were female nurses.

\section{FINDINGS}

The findings of the study are determined by measuring exogenous variable models (management's commitment to internal marketing) and endogenous variable models (formal internal marketing, informal internal marketing, responsiveness, employees' satisfaction) toward confirmatory factor analysis and confirming the relationship between the variables of the model analysis through path analysis using structural equation statistical and statistical software of LISREL. Also Sobel test was run to consider the role IM as a mediator; in the following sections it will be discussed in more details. 
Table 2

Demographic characteristics of the respondents $(N=110)$

\begin{tabular}{lccc}
\hline Demographic characteristics & & Frequency & Percent \\
\hline Gender & Men & 30 & 27.3 \\
Age (years) & women & 80 & 72.7 \\
& $<25$ & 18 & 16.4 \\
& $25-35$ & 60 & 54.5 \\
Education & $35-45$ & 30 & 27.3 \\
& $45-55$ & 2 & 1.8 \\
& High diploma & 22 & 20 \\
Working experience (years) & Bachelor & 85 & 77.3 \\
& Masters & 3 & 2.7 \\
& $<5$ & 34 & 30.9 \\
& $6-10$ & 35 & 31.8 \\
& $11-15$ & 21 & 19.1 \\
& $15-20$ & 9 & 8.2 \\
\hline
\end{tabular}

Before starting hypothesis testing, it is necessary to ensure the accuracy of the measurement models. So measurement models are presented in the following unified table. The number of measurement equitations is in accordance with the number of observed variables. Each equation includes path coefficient of the observed latent variable, measurement error of the observed variable accompanied by significant test based on $t$ and $\mathrm{R} 2$ or determined variance through latent variable.

\section{APPROVING THE MODEL}

In general, working with LISREL program, each of the indices obtained from the model cannot determine suitability and fitness of the model or verse. These indices should be interpreted together. There are several characteristics for evaluating fitness of the model which are presented in Table 4. As it can be seen degree of freedom is 1.19 and smaller than 3 which is proper enough. The low level of the index indicates little difference between the conceptual model and the observed data research. The RMSEA value is equal to 0.042 and less than 0.08 . In addition, the RMSEA index decreases, the model is a better fit. Indices (NFI-NNFI-IFI-CFI) greater than 0.9 and GFI and AGFI index is greater than 0.8 , so good model shown is approved. 
Table 3

Confirmatory factor analysis for variables

\begin{tabular}{lccccc}
\hline Latent variable & $\begin{array}{c}\text { Observed } \\
\text { variables }\end{array}$ & $\mathrm{T}$ & $\begin{array}{c}\text { Standard } \\
\text { coefficient }\end{array}$ & $\begin{array}{c}\text { Determination } \\
\text { coefficient }\end{array}$ & Error \\
\hline Management & Q1 & 9.46 & 0.78 & 0.61 & 0.092 \\
commitment to internal & Q2 & 10.92 & 0.86 & 0.73 & 0.075 \\
marketing (MCIM) & Q3 & 8.35 & 0.71 & 0.51 & 0.092 \\
Formal internal & Q4 & - & 0.80 & 0.64 & - \\
marketing & Q5 & 9.46 & 0.84 & 0.70 & 0.073 \\
& Q6 & 8.66 & 0.77 & 0.59 & 0.080 \\
& Q7 & 7.27 & 0.67 & 0.44 & 0.098 \\
Informal internal & Q8 & - & 0.75 & 0.56 & - \\
marketing & Q9 & 7.50 & 0.73 & 0.53 & 0.081 \\
& Q10 & 7.55 & 0.82 & 0.67 & 0.084 \\
& Q11 & 8.28 & 0.80 & 0.64 & 0.92 \\
& Q12 & 7.34 & 0.72 & 0.51 & 0.090 \\
Responsiveness & Q13 & - & 0.96 & 0.92 & - \\
& Q14 & 9.31 & 0.82 & 0.68 & 0.087 \\
Employees' & Financial bonds & - & 0.87 & 0.86 & - \\
satisfaction & Social bonds & 9.64 & 0.82 & 0.66 & 0.065 \\
& Structure bonds & 8.01 & 0.70 & 0.49 & 0.057 \\
\hline
\end{tabular}

All variables showed $\mathrm{t}<1.96$ and their reliability coefficient were determined properly, so none of the items (questions). So by considering all questions the researcher safely continued her work. It is necessary to mention that financial variable as observed variable had greatest effect on constructing the latent variable of employees' satisfaction, followed by social and structural variables.

Table 4

Evaluation the fit indices

\begin{tabular}{lc}
\hline Indices & Amounts reported \\
\hline & 132.49 \\
df (degree of freedom) & 111 \\
df & 1.19 \\
RMSEA (Root Mean Square Error of Approximation) & 0.042 \\
GFI (Goodness of Fit Index) & 0.87 \\
AGFI (Adjusted Goodness of Fit Index) & 0.83 \\
NFI (Normed Fit Index) & 0.96 \\
NNFI (Non-Normed Fit Index) & 0.99 \\
IFI (Incremental Fit Index) & 0.99 \\
CFI (Comparative Fit Index) & 0.99 \\
\hline
\end{tabular}


After determining confirmatory factor analysis, hypothesis testing was performed using structural analysis. Structural equation modeling was applied to test the hypothesis. This structural modeling standard mode is shown in the following figure.

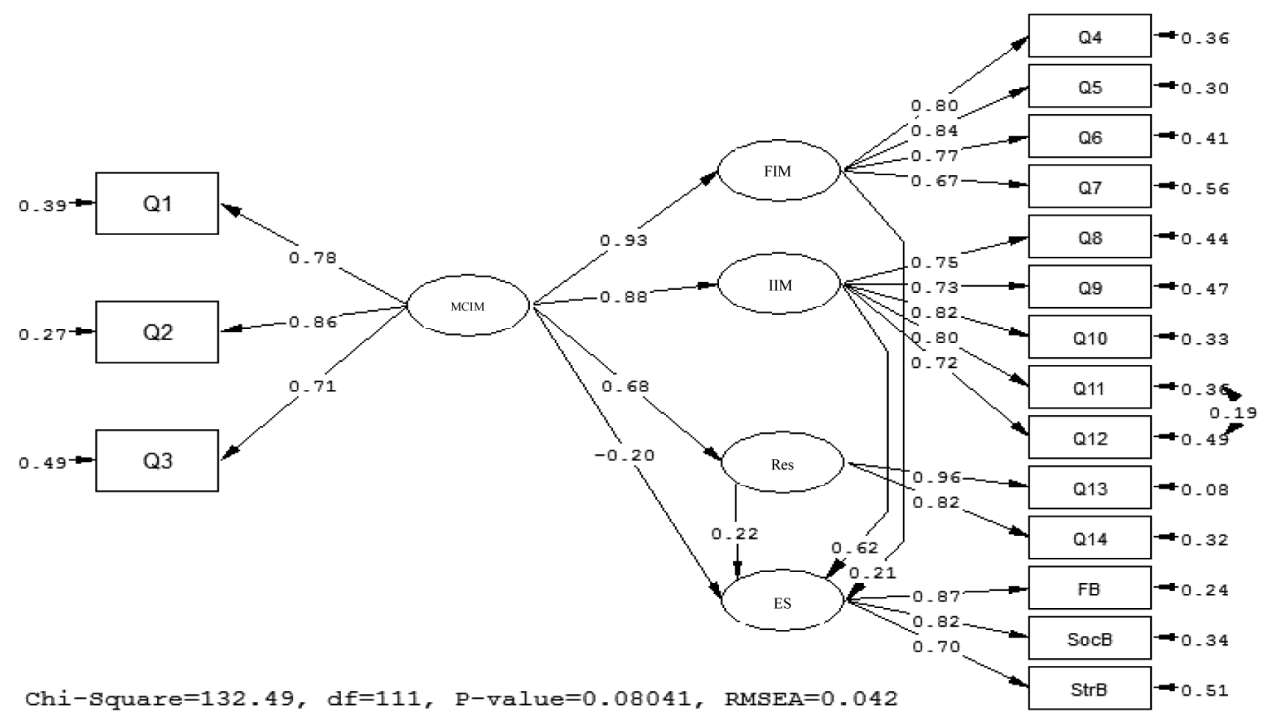

Figure 2. Model in its standard coefficient form

The above figure shows the general model in its estimated standard form. The results of the estimation (below the figure) show the suitability of the model. MCIM in model is independent variable and FIM (formal internal marketing), IIM (informal internal marketing), Res (responsiveness) and ES (employee's satisfaction) are dependent variables. Only through this kind of model, comparing observed variables which are determiners of the latent variables is possible. This model in its standard form indicates how much of the latent variable variance can be determined through the observed variable. The following table encompasses standard coefficient and $t$ of the model.

The above table shows that the determining coefficient for employees' satisfaction is $60 \%$. This indicates that MCIM, formal internal relations, informal internal relations and answering altogether can only explain $60 \%$ of employees' satisfaction. According to the standard coefficient and the amount of $t$, one can say that informal internal marketing has a positive effect on employees' satisfaction, and MCIM, and formal internal marketing and responsiveness variables has no meaningful effect. It says that $86 \%$ of formal internal marketing changes are determined through 
MCIM. The table also shows that $78 \%$ of informal internal marketing changes are explained through MCIM. In this way it can be said that $46 \%$ of answering changes are determined through the management commitment variable.

Table 5

Summary of standard coefficient, determination coefficient $\left(R^{2}\right)$, $t$ and results

\begin{tabular}{lcccc}
\hline Path & $\begin{array}{c}\text { Standard } \\
\text { coefficient }\end{array}$ & $\mathrm{T}$ & $\begin{array}{c}\text { Determination } \\
\text { coefficient }\left(\mathrm{R}^{2}\right)\end{array}$ & Results \\
\hline $\begin{array}{l}\text { Management commitment to internal marketing } \\
(\mathrm{MCIM}) \rightarrow \text { Formal internal marketing }\end{array}$ & 0.93 & 8.91 & 0.86 & Approve \\
$\begin{array}{l}\text { Management commitment to internal marketing } \\
(\mathrm{MCIM}) \rightarrow \text { Informal internal marketing }\end{array}$ & 0.88 & 7.81 & 0.87 & Approve \\
$\begin{array}{l}\text { Management commitment to internal marketing } \\
\text { (MCIM) } \rightarrow \text { Responsiveness }\end{array}$ & 0.68 & 7.41 & 0.46 & Approve \\
$\begin{array}{l}\text { Management commitment to internal marketing } \\
\text { (MCIM) } \rightarrow \text { Employees' satisfaction }\end{array}$ & -0.20 & -0.40 & 0.60 & Reject \\
$\begin{array}{l}\text { Formal internal marketing } \rightarrow \text { Employees' } \\
\text { satisfaction }\end{array}$ & 0.21 & 0.58 & & Reject \\
$\begin{array}{l}\text { Informal internal marketing } \rightarrow \text { Employees' } \\
\text { satisfaction }\end{array}$ & 0.62 & 2.38 & & Approve \\
Responsiveness $\rightarrow$ Employees' satisfaction & 0.22 & 1.85 & & Reject \\
\hline
\end{tabular}

\section{HYPOTHESIS TESTING}

After investigating and approving the model, the hypotheses were tested. Also the mediating role of the variables was investigated by using Sobel test.

According to Table (5) Hypothesis 1,2 and 3 are approved. Therefore it is cocludeded that management commitment to the internal marketing has a positive effect on the formal internal marketing, informal internal marketing and responsiveness.

But Hypothesis 4 and 5 is rejected and both variables management commitment to the internal marketing and formal internal marketing have no effect on employees' satisfaction.

According to Table (5) Hypothesis 6 is approved. This means that there was a meaningful relation between informal internal marketing and employees' satisfaction. But Hypothesis 7 is rejected and responsiveness has no effect on employees' satisfaction. 
According to the Table (6) Hypothesis 8 is rejected. So MCIM through the informal internal marketing has no effect on employees' satisfaction. But Hypothesis 9 is approved. So since there is no direct relation between MCIM and employees' satisfaction, the informal internal marketing variable play a mediating role, and MCIM through informal internal marketing affects employees' satisfaction.

Finally Hypothesis 10 is rejected. So MCIM through the responsiveness has no effect on employees' satisfaction.

Table 6

The role of mediating variables using Sobel test

\begin{tabular}{lcccc}
\hline Mediating Variables & $\mathrm{Z}$ & $\mathrm{P}$ & $\mathrm{S} . \mathrm{E}$ & Effect of standard indirect \\
\hline formal internal marketing & 0.567 & 0.345 & 0.571 & 0.195 \\
informal internal marketing & 2.323 & 0.239 & 0.020 & 0.546 \\
responsiveness & 1.779 & 0.084 & 0.075 & 0.150 \\
\hline
\end{tabular}

\section{DISCUSSION AND CONCLUSION}

The results of hypothesis testing and statistical analysis show that MCIM has a meaningful effect on different ways of IM (formal internal marketing, informal internal marketing and responsiveness). To et al. (2015) in their study confirmed the first three hypotheses. But opposite to what is supposed, there was no meaningful relation between MCIM on employees' satisfaction. It seemed that for participants financial necessities had priority over structural and social affairs. While Peltier et al., (2003, 2004) and Pelletier et al., (2007) in their studies showed that social and structural affair were more important than the financial ones. Also, among different internal marketing methods only the informal internal marketing method had a meaningful effect on employees' satisfaction, directly or indirectly. This means that the informal internal marketing is more effective than the formal internal marketing.

This is highly consistent with evidence from this study that informal internal marketing directly affects employees' satisfaction, while formal internal marketing does not have a major impact on it. Regarding the results obtained through these surveys, with the emphasis on developing informal internal marketing, the management can lay the base for improving employees' satisfaction, while the formal internal marketing will not enhance it considerably. As Rafiq \& Ahmed (2000) argued that Managers should focus on communicating with their 
subordinates in a way that employees understand their vital roles in achieving organizational objectives (Rafiq \& Ahmed, 2000). Also A study by Cowherd and Levine (1992) suggests that internal customer' satisfaction affects the quality of products, which in turn influences external customer' satisfaction (Bansal et al., 2001). Thus, informal internal Marketing leads to increased employees' satisfaction, which leads to improved service quality and customer' satisfaction.

We challenge researchers to consider the broader implications of satisfaction related factors and the relationship between internal marketing and employees' satisfaction in other hospitals and organisations.

\section{REFRENCES}

Abzari, M., Ghorbani, H., \& Madani, F. (2011). The effect of internal marketing on organizational commitment from market-orientation, viewpoint in hotel industry in Iran. International Journal of Marketing Studies, 3(1), 147-155. https://doi. org/10.5539/ijms.v3n1p147

Acker, G.M. (2004). The effect of organizational conditions (role conflict, role ambiguity, opportunities for professional development, and social support) on job satisfaction and intention to leave among social workers in mental health care. Community Mental Health Journal, 40(1), 65-73. https://doi.org/10.1023/ B:COMH.0000015218.12111.26

Ahire, S. L., \& O'Shaughnessy, K. C. (1998). The role of top management commitment in quality management: an empirical analysis of the auto parts industry. International Journal of Quality Science, 3(1), 5-38. https://doi. org $/ 10.1108 / 13598539810196868$

Aiken, L. H., Clarke, S. P., Sloane, D. M., Sochalski, J. A., \& Silber, J. H. (2002). Hospital nurse staffing and patient mortality, nurse burnout, job dissatisfaction. Journal of the American Medical Association, 288(16), 1987-1993. https://doi.org/10.1001/ jama.288.16.1987

Arnett, D. B., Laverie, D. A., \& Mclane, C. (2002). Using job satisfaction and pride as internal-marketing tools. Cornell Hotel Restaur. Adm. Quart, 43(2), 87-96. https://doi.org/10.1016/S0010-8804(02)80035-0

Bansal, H. S., Mendelson, M. B., \& Sharma, B. (2001). The impact of internal marketing activities on external marketing outcomes. Journal of Quality Management, 6 , 61-76. https://doi.org/10.1016/S1084-8568(01)00029-3

Berry, L. L., Hensel, J. S., \& Burke M. C. (1976). Improving retailer capability for effective consumerism response. Journal Retail, 52(3), 3-14.

Berry, L. L. (1981). The employee as a customer. Journal of Retail Banking, 3, 33-44.

Berry, L. L., \& Parasurman, A. (1991). Marketing Services, Competing through quality. New York, The Free Press. 
Cascio, R., Mariadoss, B. J., \& Mouri, N. (2010). The impact of management commitment alignment on salespersons' adoption of sales force automation technologies: An empirical investigation. Industrial Marketing Management, 39, 1088-1096. https://doi.org/10.1016/j.indmarman.2009.12.010

Christen, M., Iyer, G., \& Soberman, D. (2006). Job satisfaction, job performance, and effort: A reexamination using agency theory. Journal Market, 70(1), 137-150. https://doi.org/10.1509/jmkg.2006.70.1.137

Cheung, M. F. Y., \& To, W. M. (2010). Management commitment to service quality and organizational outcomes. Managing Service Quality, 20(3), 259-272. https://doi. org/10.1108/09604521011041970

Cooper, J., \& Cronin, J. J. (2000). Internal Marketing: A competitive strategy for the long term care industry. Journal of Business Research, 48(3), 177-181. https://doi. org/10.1016/S0148-2963(98)00084-8

Cowherd, D. M., \& Levine, D. I. (1992). Product quality and pay equity between lower-level employees and top management: an investigation of distributive justice theory. Administrative Science Quarterly, 37, 302-320. https://doi.org/10.2307/2393226

Dabholkar, P. A., \& Abston, K. A. (2008). The role of customer contact employees as external customers: A conceptual framework for marketing strategy and future research. Journal of Business Research, 61, 959-967. https://doi.org/10.1016/j. jbusres.2007.10.004

George, W. R. (1977). The retailing of services a challenging future. Journal Retail, 53(3): 85-98.

Gounaris, S. P. (2006). Internal market orientation and its measurement. Journal of Business Research. 59(4), 432-448. https://doi.org/10.1016/j.jbusres.2005.10.003

Hogg, G., Carter, S., \& Dunn, A. (1998). Investing in people: Internal marketing and corporate culture. Journal of Marketing Management, 14(8), 879-895. https:// doi.org/10.1362/026725798784867563

Huang, Y.T., \& Rundle-Thiele, S. (2014). The moderating effect of cultural congruence on the internal marketing practice and employee satisfaction relationship: An empirical examination of Australian and Taiwanese born tourism employees. Tourism Management, 42, 196-206. https://doi.org/10.1016/j.tourman.2013.12.005

Kelliher, C., \& Riley, M. (2003). Beyond Efficiency: Some by-Products of functional flexibility. The Service Industries Journal, 23(4), 98-113. https://doi.org/10.1080 /02642060412331301032

Kiburn, A. J. (2009). Building quality internal exchange: The role of the organizational and the individual in internal customer orientation. Acad. Mark. Stud. J., 13(1), 79-87.

Kim, H.J., Tavitiyaman, P., \& Kim, W.G. (2009). The effect of management commitment to service on employee service behaviors: the mediating role of job satisfaction. Journal of Hospitality and Tourism Research, 33(3), 369-390. https://doi. org/10.1177/1096348009338530

Lings, I. N., \& Greenley, G. E. (2005). Measuring internal marketing orientation. Journal of Services Researc, 7(3), 290-305. https://doi.org/10.1177/1094670504271154 
Lings, I. N. (2004). Internal market orientation construct and consequences. Journal of Business Research, 57, 405-413. https://doi.org/10.1016/S0148-2963(02) 00274-6

Luo, X., Wieseke, J., \& Homburg, C. (2012). Incentivizing CEOs to build customer and employee-firm relations for higher customer satisfaction and firm value. J. Acad. Mark. Sci., 40(6), 745-758. https://doi.org/10.1007/s11747-011-0290-1

Martin Jr, E. F., \& To, W.M. (2013). Effect of internal market orientation on organizational performance: The case of Macao's gaming industry. International Journal of Hospitality and Tourism Administration, 14, 233-254. https://doi.org/10.1080/1 5256480.2013.809980

Melten, S., Eveleth, D., \& Bailey, J. J. (2005). Management support and perceived consumer satisfaction in skilled nursing facilities. Health Services Management Research, 18(3), 198-210. https://doi.org/10.1258/0951484054572510

Moorman, C., Zaltman, G., \& Dehpande, R. (1992). Relationships between providers and users of market research: the dynamics of trust within and between organizations. Journal of Marketing Research, 29, 314-328. https://doi.org/10.2307/3172742

Murray, J. G. (1979). The importance of internal marketing. Bankers Magazine, 38-40.

Newman, K. (2001). Interrogating SERVQUAL: A critical assessment of service quality measurement in high street retail bank. International Journal of Bank Marketing, 19(3), 126-139. https://doi.org/10.1108/02652320110388559

Paille, P., \& Boiral, O. ( 2013). Pro-environmental behavior at work: Construct validityand determinants. Journal of Environmental Psychology, 36, 118-128. https://doi. org/10.1016/j.jenvp.2013.07.014

Paulin, M., Ferguson, R. J., \& Bergeron, J. (2006). Service climate and organizational commitment: The importance of customer linkages. Journal Bus. Res., 59(8), 906-915. https://doi.org/10.1016/j.jbusres.2006.03.004

Pelletier, L. G., Kabush, D. Vallerand, R. J., \& Sharp, E. C. (2007). The revised SMS: support for the integrated regulation subscale. University of Ottawa, in preparation.

Peltier, J. W., Boyt, T., \& Westfall, J. E. (1997). Building relationships with physicians. Marketing Health Services, 17(3), 12-18.

Peltier, J. W., \& Scovotti, C. (2004). Relationship marketing and disadvantaged health care segments: using internal marketing to improve the vocational rehabilitation process. Health Marketing Quarterly, 22(2), 69-90. https://doi.org/10.1300/ J026v22n02_05

Peltier, J. W., Boyt, T., \& Schibrowsky, J. A. (1998). Relationship building: Measuring service quality across health care encounters. Marketing Health Services, 18(3), $17-24$.

Peltier, J. W., Pointer, L., \& Schibrowsky, J. A. (2006). Internal marketing and the antecedents of nurse satisfaction and loyalty. Health Marketing Quarterly, 23(4), 74-108. https://doi.org/10.1080/07359680802131582

Peltier, J., Nill, A., \& Schibrowsky, J. A. (2003). Internal marketing, nurse loyalty and relationship marketing: An exploratory study of German nurses. Health Marketing Quarterly, 20(4), 63-82. https://doi.org/10.1300/J026v20n04_05 
Rafiq, M., \& Ahmed, P. K. (1993). The scope of internal marketing: Defining the boundary between marketing and human resource management. Journal of Marketing Management, 9, 219-232. https://doi.org/10.1080/0267257X.1993.9964234

Rafiq, M., \& Ahmed, P. K. (2000). Advances in the internal marketing concept: Definition, synthesis and extension. Journal of Services Marketing, 14(6), 449-462. https:// doi.org/10.1108/08876040010347589

Spence Laschinger, H. K., Finegan, J. E., Shamian, J., \& Wilk, P. (2004). A longitudinal analysis of the impact of workplace empowerment on work satisfaction. Journal of Organizational Behavior, 25(4), 527-545. https://doi.org/10.1002/job.256

Stachowski, C. A. (2008). Managing internal marketing in a New Zealand language school (some important lessons for all educational Leaders). Management and Administration Society, 22(4), 31-38. https://doi.org/10.1177/0892020608093264

Stauss, B., \& Schulze, H. S. (1990). Internets Marketing, Marketing ZFP, 12(3), 149-158.

Sulaiman, Y., Othman, A. R., Perumal, S., \& Hashim, N. A. (2013). The relationship between the different aspects of internal market orientation and affective commitment within Malaysia childcare sector. Journal of Marketing Management, 1(1), 13-21.

Timmreck, T. C. (2006). Managing motivation and developing job satisfaction in the health care work environment. Health Care Manag, 20(1),42-58.

To, W. M., Martin Jr, E. F., \& Yu, B. T. W. (2015). Effect of management commitment to internal marketing on employee work attitude. International Journal of Hospitality Management, 45, 14-21. https://doi.org/10.1016/j.ijhm.2014.11.002

Woods, D., \& Cardin, S. (2002). Realizing your marketing influence, marketing from inside-out. Journal of Nursing Administration, 32(6), 323-330. https://doi. org/10.1097/00005110-200206000-00008 